sediment plumes, sometimes leading to fatal clashes with South Korea's coastguard. In 2011, a Chinese fisherman stabbed a Korean coastguard to death with a shard of broken window glass; in a separate 2014 skirmish, the Korean coastguard shot and killed a Chinese fisherman.

The dispute has also prevented cooperation in assessing the deterioration of the Yellow Sea's marine ecosystem. Dams in Chinese rivers have interrupted the once-steady flow of sediment and nutrients into the waters, and pollution has created enormous algal blooms. Urbanization has also claimed most of the tidal flats that once ringed the Yellow Sea basin, threatening key habitats for migratory birds.

Monitoring and management of the basin requires collaboration, says Paul Liu, an oceanographer at North Carolina State University in Raleigh. South Korean and Chinese ocean researchers do share some data through a joint marine-research centre in Qingdao, which has held workshops and coordinated some work since 1995. But when asked about the boundary dispute, Wei Zheng, the centre's vice-director, said: "It still is a problem." She declined to comment further, citing the sensitivity of the issue.

Choi, for example, says that he and his colleagues would like to conduct a deep seismic

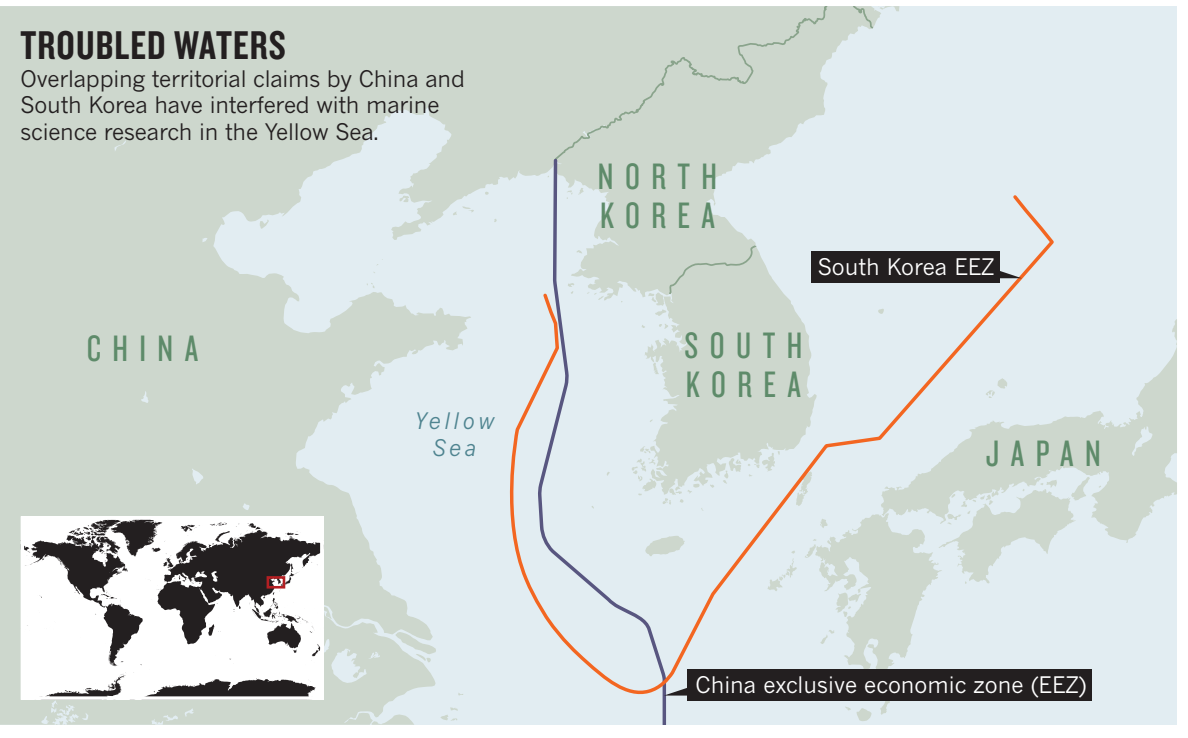

survey transecting the entire Yellow Sea. But he says that the project would need permission and protection from China's coastguard to prevent passing fishing boats causing any damage to the kilometres-long cables and attached equipment.

Both Liu and Yang say that an agreement would similarly foster collaborations to look at how sediments have swirled across the Yellow Sea in the past, and how new dams on China's rivers have changed that process. "The Chinese cannot only study the western side, or Koreans cannot only study the eastern side," Liu says. "They have to work together to know the whole picture of the area."

\title{
Europe's genetically edited plants stuck in legal limbo
}

\section{Scientists frustrated at delay in deciding if GM regulations apply to precision gene editing.}

\section{BY ALISON ABBOTT}

$\mathrm{P}$ lant geneticist Stefan Jansson is champing at the bit to start field trials on crops tweaked with powerful gene-editing technologies. He plans to begin by using edits to study how the cress plant Arabidopsis protects its photosynthetic machinery from damage in excessively bright light.

But the future of his work depends on the European Commission's answer to a legal conundrum. Should it regulate a gene-edited plant that has no foreign DNA as a genetically modified (GM) organism?

Jansson, who works at Umeå University in Sweden, says that he will drop his experiments if the plants are classed as GM, because Europe's onerous regulations would make his work too expensive and slow. He and many others are anxiously awaiting the commission's decision, which will dictate how they approach experiments using the latest gene-editing techniques, including the popular CRISPR-Cas9 method.

The commission has repeatedly stalled on delivering its verdict, which will apply to edited animals and microorganisms as well as plants. It now says that it will make its legal analysis public by the end of March. Swedish authorities, meanwhile, have told Jansson that unless the commission specifies otherwise, they will not require his cress to be subject to GM regulations.

\section{GENETIC EDITING}

The legal limbo is having a big impact on research, says René Smulders of the plantbreeding division at Wageningen University and Research Centre in the Netherlands. He says that this year, he was rejected for a European Union grant - on changing the composition of a plant's oils by editing a gene - because referees were concerned about the legal uncertainty. "Some scientists hesitate to start using the new methods in case they end up being regulated and their research projects hit a dead end," he says.

At issue is the interpretation of a 2001 European Commission directive on releasing GM organisms into the environment, which covers field trials and cultivation. It defines GM organisms as having alterations that cannot occur naturally, which were made by genetic engineering.

What is unclear is how this relates to experiments, such as Jansson's, in which researchers introduce foreign DNA to direct a precise edit in a plant's own genetic material but then use selective breeding to remove the foreign gene. The final plant has a few tweaked nucleotides, but cannot be distinguished from a wild plant that might have acquired the same mutation naturally - so it cannot be traced in the environment as EU regulations require.

Many EU member states - including Sweden - have conducted their own analyses of the directive, and argue that it should not apply to edited plants that do not contain foreign DNA. But some non-governmental organizations 
- (NGOs) hostile to genetic manipulation have produced analyses that conclude the directive should apply because genetic engineering is involved.

Academic scientists and seed and crop companies fear that plants made with the latest gene-editing techniques may share the fate of conventional GM plants in Europe. Strict regulations, cumbersome bureaucracy and activism against GM organisms have meant that scientists in some countries, such as Germany, do not even attempt field trials. The regulations have increased the costs of bringing a GM crop to market, and many European nations do not allow such crops to be cultivated at all. That is frustrating for plant scientists who want their work to be useful to the world, says Jonathan Jones, a plant researcher at the Sainsbury Laboratory in Norwich, UK.

"We hoped that the new plant-breeding techniques would offer ways of achieving the same outcome without the onerous regulations - and fear that might not turn out to be the case," he says.

Many countries outside Europe do not face the same uncertainty, because they regulate GM organisms according to the nature of the product, not how it was made. In the United States, gene-edited crops containing no foreign genetic material are assessed on a case-by-case basis. In 2004, the biotechnology company Cibus, based in San Diego, California, was told that the US Department of Agriculture would not need to regulate its herbicide-resistant oilseed rape, made with an earlier form of gene-editing. Its crop is now cultivated in the United States. (The White House did, however, begin a review of all US biotechnology regulation in July.)

Since 2011, Cibus has asked six countries - Finland, Germany, Ireland, Spain, Sweden and the United Kingdom - whether they would consider its crop to come under the scope of the EU directive. Without guidelines from the commission, each conducted its own analysis and said that it would not. Cibus has now done field trials in the United Kingdom and Sweden, but it put its activities on hold after the commission sent a letter to all EU member states on 15 June, asking them to wait for its legal interpretation.

Whatever the commission decides, it is likely that either a member state, an NGO or a company will sue - meaning that the European Court of Justice may make the final, binding decision on the matter.

Many plant scientists do basic research, so their gene-edited plants never need to leave the greenhouse. But Jansson must plant his cress outside to test its photosynthetic abilities in natural conditions. With his country's approval, he plans to plant the crop in the spring. "Lawyers talk and talk - I think it is important for Europe to have a test case," he Says. - SEE EDITORIAL P.307

\section{German researchers pledge refugee help}

\section{Social scientists launch integration studies and warn of need to counter rising xenophobia.}

\section{BY QUIRIN SCHIERMEIER}

A fter civil war broke out in Syria, Mohammad Khamis lost his parents and his home - but not his dream of becoming a scientist. In July 2013, he boarded a flight from Damascus, where he had studied electrical engineering, to Egypt. In Alexandria, he paid traffickers about $€ 5,000$ (US\$5,500) for a boat passage to Europe. The 9-day voyage to the Italian island of Lampedusa, on an unseaworthy sloop with 100 other desperate refugees, was a nightmare of fear, vomit and thirst.

Two years later, Khamis, now 22, is attending classes in maths, physics and chemistry at the Technical University of Munich (TUM) in Germany, where he sought asylum in August 2013 and was last year accepted as a war refugee. "There is no future for me in Syria," he says on a cold December day in Munich. "I would like to stay here to study and find a good research job. My dream is to discover something new."

Social scientists studying the flow of refugees into Germany want to discover something themselves: how many of the incoming people are, like

\section{"Science has a responsibility to help tackle the huge integration challenge ahead."}

Khamis, well-qualified, motivated and eager to learn - a boon for the economy. These migration researchers say that Germany has become a case study in the difficulties of suddenly integrating a large group of culturally diverse foreigners into a society; the nation has registered nearly one million asylum-seekers this year, more than half of them from Syria. It is the highest such influx in Western Europe.

After a short-lived wave of hospitality in September, when chancellor Angela Merkel promised that Germany would be a welcoming host to the persecuted, many citizens and some right-leaning politicians have begun to voice concerns, painting a picture of a Muslimdominated parallel society of poorly trained recipients of social welfare.

Research may be able to counter the rising tide of xenophobia and aid the urgent process of resettling refugees by revealing more about migrants' skills and cultural values, says
David Schiefer, a Berlin-based psychologist with a German advisory body on migration and integration who is planning interviews with refugees. "We need to give these people a voice," he says.

With about half of the newcomers under 25 years of age, Germany's higher-education and science systems have a particular obligation - and the well-funded capacity - to help, say researchers. "Science has a responsibility to help tackle the huge integration challenge ahead," says Alexander Kurz, head of human resources at the Fraunhofer Society in Munich, which runs centres for applied research. "There is great readiness among our staff of 25,000 scientists from 100 nations to provide mentorship and practical help."

\section{LISTENING TO REFUGEES}

Reliable data on refugees' qualifications and backgrounds are lacking. "We're poking around in the fog," says Ludger Wößmann, a director of the Ifo Center for the Economics of Education in Munich. International assessments of 15-year-olds suggest that up to twothirds of Syrian refugee students might lack basic reading, writing and maths skills, he says. German industrial groups say that the large majority of migrants have minimal skills and poor language abilities, making them hardly employable.

But these assumptions are ill-informed, says Steven Vertovec, director of the Max Planck Institute for the Study of Religious and Ethnic Diversity in Göttingen. In fact, the newcomers are probably as diverse as German society at large, he says. "There are many highly educated, secularized people among the Syrians, Iraqis and Afghans who are seeking asylum here."

Vertovec is leading a study in Lower Saxony in northern Germany that aims to interview asylum-seekers to examine their needs and aspirations, as well as to uncover best practices for responding to refugees. The goal is to produce practical guidelines for city workers and volunteer social workers in asylum-seeker camps on how to work with groups of migrants who may differ enormously in age, religion, language and education status. "Successful integration requires a nuanced understanding of migrants' backgrounds and values," he says. 